\title{
АНАЛИЗ ВОЗМОЖНОСТИ ПОВЫШЕНИЯ СВОЙСТВ МАТЕРИАЛА ВК15 ДЛЯ БУРОВОГО ИНСТРУМЕНТА
}

\author{
Ю.А.КУРГАНОВА ${ }^{1}$, К.С.ПАНИНА ${ }^{1}$, П.С.БЕШЕНКОВ ${ }^{2}$ \\ ${ }_{1}^{1}$ Московский государственный технический университет им. Н.Э.Баумана, Москва, Россия \\ ${ }^{2}$ ООО «Завод технической керамики», г. Апрелевка, Московская обл., Россия
}

\begin{abstract}
Традиционно при бурении крепких, весьма крепких и абразивных горных пород рекомендуется применять вольфрамокобальтовый твердый сплав ВК15. Мониторинг информационных источников по вопросу возможностей повышения потенциала материала продемонстрировал наличие механизмов, обеспечивающих структурные превращения, провоцирующие повышение показателей прочности, твердости и ударной вязкости материала. Применение таких технологических приемов взамен традиционных приведет к повышению эффективности работы и срока эксплуатации инструмента. В ходе работы получены экспериментальные образцы сплава ВК15, спеченные по четырем разным модернизированным режимам. На полученных экспериментальных образцах проведен сравнительный анализ свойств. Результаты металлографического исследования, осуществляемого на микроскопе «Carl Zeiss», позволили оценить распределение зерен карбида вольфрама в кобальтовой связке и продемонстрировать измельчение карбидной фазы. Так, при традиционном спекании количество зерен карбида вольфрама средним размером менее 1 мкм в диаметре от всего размерного диапазона достигает $19,5 \%$, в то время как после дополнительной термической обработки с выдержкой $1280{ }^{\circ} \mathrm{C}-41,5 \% ; 900{ }^{\circ} \mathrm{C}-59,1 \% ; 600^{\circ} \mathrm{C}-54,5 \%$. Максимальное из исследуемых экспериментальных образцов увеличение твердости на $18 \%$, коэрцитивной силы - на $49 \%$, трещиностойкости - на $11 \%$ традиционного сплава достигнуто на режиме $900-1280^{\circ} \mathrm{C}$. Выдвинута гипотеза о формировании дополнительных структурных элементов, не выявляемых методами оптической металлографии. Исследования топологии и структуры образцов на атомно-силовом микроскопе подтвердили наличие наноразмерных включений от 20 до 40 нм, предположительно карбида вольфрама, в кобальтовой связке.

Для ВК15 сравнительные исследования свойств и анализ микроструктуры экспериментальных образцов, полученных по традиционному режиму спекания и модернизированной технологии, показали, что режим спекания при $900{ }^{\circ} \mathrm{C}$ является приоритетным. Таким образом, разработанная технология, включающая спекание порошков в протоке водорода до $750{ }^{\circ} \mathrm{C}$, с 750 до1450 ${ }^{\circ} \mathrm{C}$ в вакууме, подачу на максимальной температуре $1450{ }^{\circ} \mathrm{C}$ в течение 15 мин аргона под давлением 60 бар, последующее охлаждение до $900{ }^{\circ} \mathrm{C}$ и выдержку в течение часа, может быть рекомендована как наиболее рациональная для раскрытия потенциала материала и обеспечения повышенного уровня свойств бурового инструмента.

Ключевые слова: вольфрамокобальтовый твердый сплав; буровой инструмент; температурный интервал; термообработка
\end{abstract}

Как цитировать эту статью: Курганова Ю.А. Анализ возможности повышения свойств материала ВК15 для бурового инструмента / Ю.А.Курганова, К.С.Панина, П.С.Бешенков // Записки Горного института. 2018. T. 233. C. 518-524. DOI: 10.31897/PMI.2018.5.518

Введение. В настоящее время Российская Федерация является ведущей страной в мире по добыче полезных ископаемых. Около 90 \% объема буровых работ выполняется шарошечными буровыми долотами. При помощи инструмента, оснащенного твердыми сплавами, производится вырубка, бурение геологоразведочных скважин, бурение промышленных скважин на нефть, газ, воду, бурение скважин для взрыва горной массы и пород. Эксплуатационные свойства бурового инструмента определяются физико-механическими свойствами материала, выбранного для рабочих частей. При бурении крепких, весьма крепких и абразивных горных пород рекомендуется применять твердый сплав ВК15 [2]. Сплав относится к вольфрамокобальтовым твердым сплавам, структура которых состоит из зерен карбида вольфрама и кобальта. Данная группа сплавов обладает высокими показателями твердости, износостойкости и теплостойкости [5].

Постановка проблемы. Потребности современного производства и мониторинг информационных источников по данному вопросу позволили выявить возможности достижения повышенных прочности и ударной вязкости за счет упрочненной кобальтовой связки. Например, использование таких приемов, как модифицирование кобальтовой связки нанодобавками приводит к повышению срока эксплуатации инструмента $[1,3,4,7,10-13,15-17]$. Данные методы способствуют значительному росту комплекса механических свойств, однако являются дорогостоящими. Помимо изменения гранулометрического и химического состава исходных компонентов, на структуру и свойства сплавов влияет термическая обработка $[8,14]$.

В настоящей работе предложено обоснование и результаты опробования модернизированного технологического процесса получения порошковой заготовки путем дополнения операции охлаждения после спекания и повторного нагрева $[6,9]$. 
Анализ возможности повышения свойств материала ВК15 для бурового инструмента

a

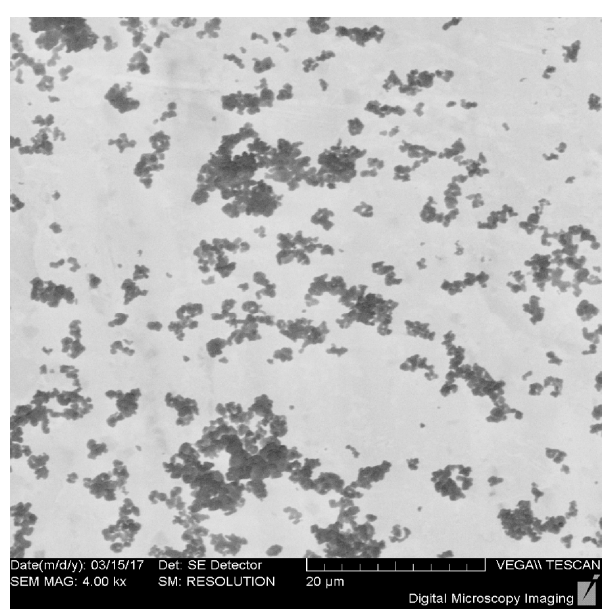

$\sigma$

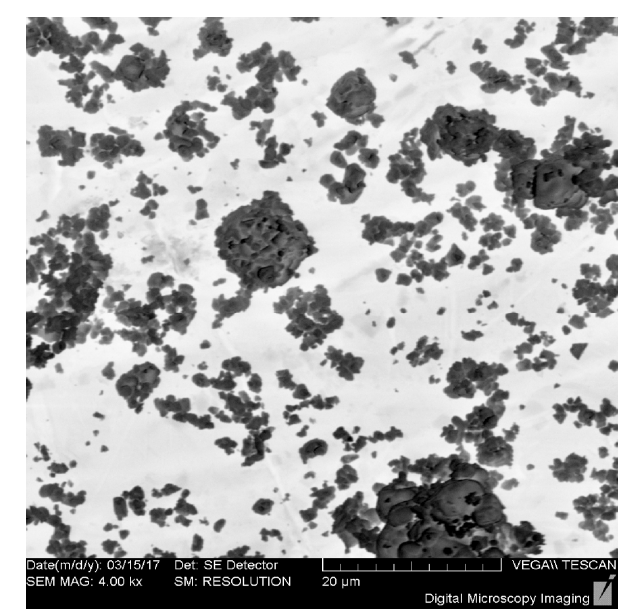

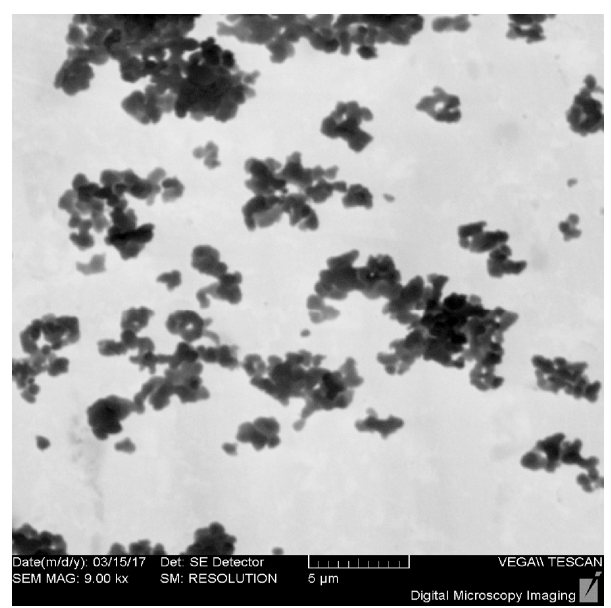

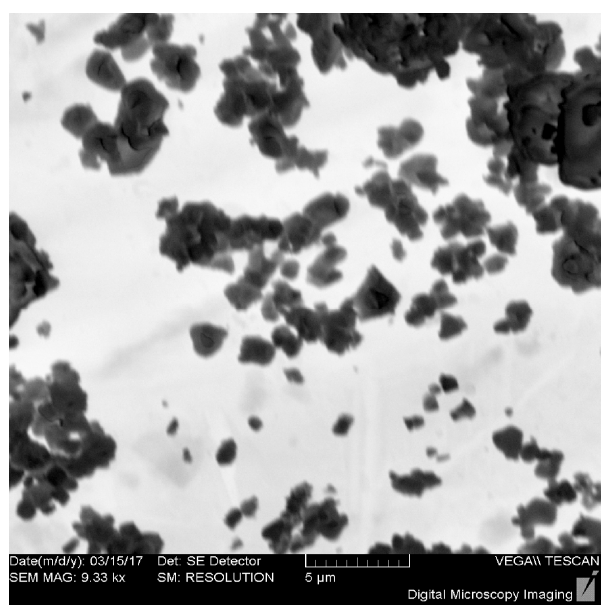

Рис.1. Порошок Со (a) и WC (б) при увеличении $4000^{\mathrm{x}}$ и $9000^{\mathrm{x}}$

a

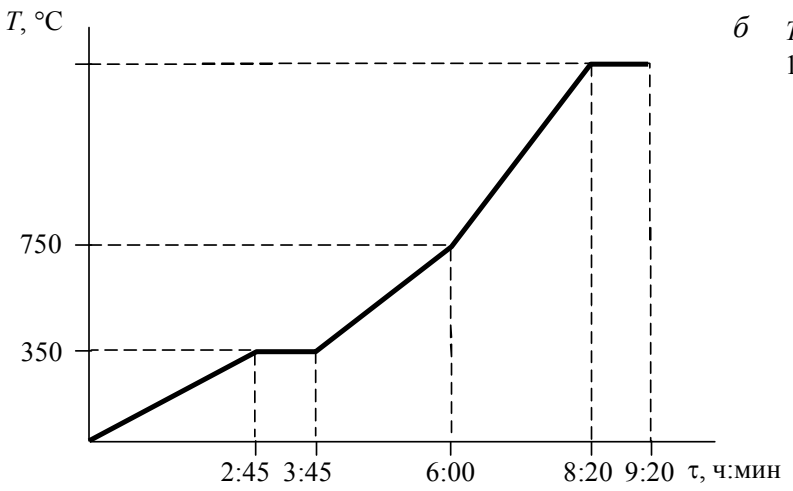

$\sigma \quad T,{ }^{\circ} \mathrm{C}$

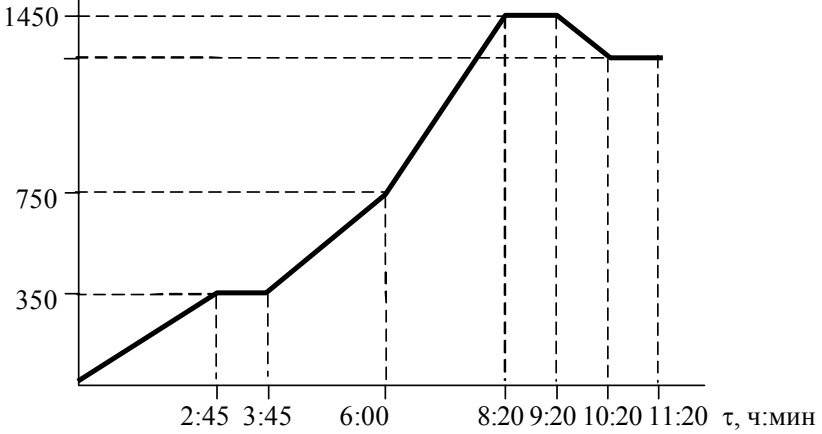

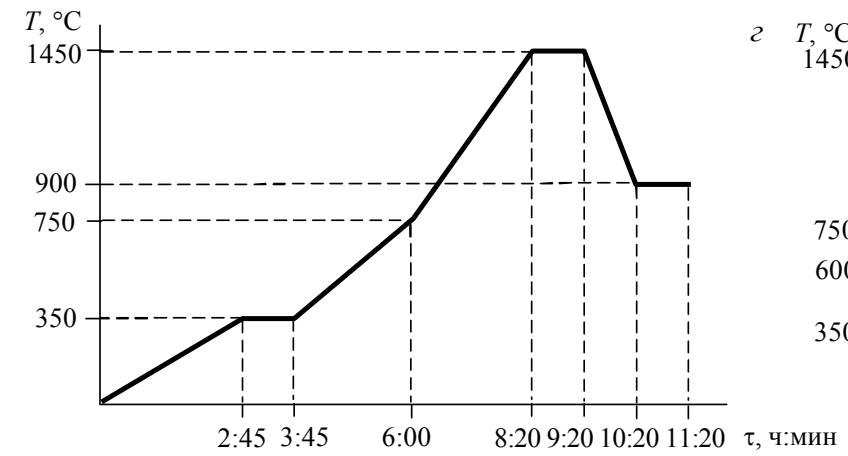

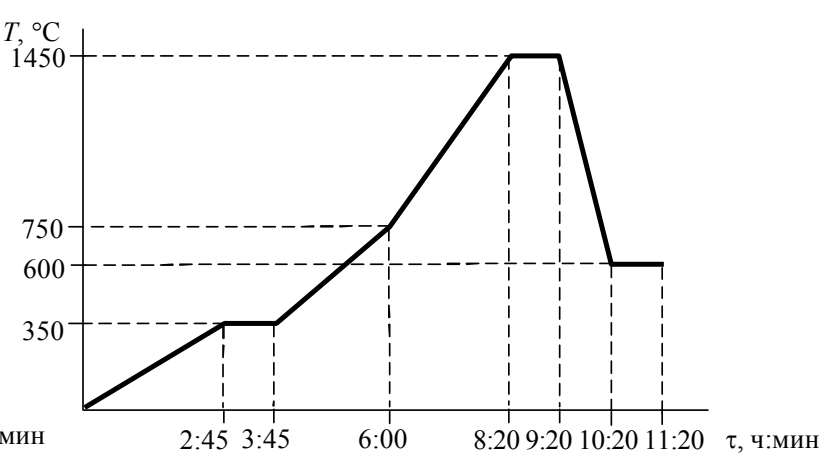

Рис.2. Графики режимов термообработки: традиционного (a) и режима спекания с дополнительной выдержкой при температурах $1280^{\circ} \mathrm{C}\left(\right.$ б); $900^{\circ} \mathrm{C}\left(\right.$ (в); $600{ }^{\circ} \mathrm{C}$ (2) 
Методология. Исходными материалами объекта исследования взяты порошки карбида вольфрама марки WC3 (ТУ 1742-002-46878311-2013) со средним размером частиц порошка D50 = 3 \pm 1 мкм и кобальт марки ПК-1У (ГОСТ 9721-79) со средним размером 1,2士0,2 мкм. Контроль гранулометрического состава осуществлялся на приборе «Malvern Mastersizer 3000Е».

Химический состав исходных порошков следующий:

$\begin{array}{lcccccccccccc}\text { Компонент } & \mathrm{Mo} & \mathrm{Si} & \mathrm{Fe} & \mathrm{Na}+\mathrm{K} & \mathrm{Pb} & \mathrm{Ni} & \mathrm{Mn} & \mathrm{Ca} & \mathrm{Al} & \mathrm{S} & C_{\text {общ }} & C_{\text {своб }} \\ \mathrm{WC} & 0,18 & 0,003 & 0,100 & 0,010 & - & - & - & 0,005 & 0,003 & 0,023 & 6,12 & 0,050 \\ \mathrm{Co} & - & 0,001 & 0,002 & 0,002 & 0,001 & 0,03 & 0,001 & 0,001 & - & 0,001 & 0,015 & -\end{array}$

Исследования исходных порошков проводились на растровом электронном микроскопе VEGA II LMH в лаборатории тонких физических методов исследования структуры материалов МГТУ им. Баумана (рис.1).

Смесь порошков размалывали в среде изопропилового спирта в валковой мельнице мокрого размола. Далее проводилась сушка, замешивание с раствором синтетического каучука в бензине и прессование полученной смеси в стальных формах под давлением 100 МПа. Спекание прессовок в вакуумно-компрессионной печи ПВК-1 осуществлялось в различных режимах для определения наиболее эффективного. Все технологические операции выполнены на базе ООО «Завод технической керамики» (табл.1).

Таблииа 1

Режимы спекания

\begin{tabular}{|c|c|c|c|c|}
\hline \multirow{2}{*}{ Номер режима } & \multicolumn{3}{|c|}{ Температурный режим } & \multirow{2}{*}{ Назначение операции } \\
\hline & Температура, ${ }^{\circ} \mathrm{C}$ & Скорость нагрева, ${ }^{\circ} \mathrm{C} /$ мин & Выдержка, мин & \\
\hline 1 & $\begin{array}{c}\leq 350 \\
350 \\
350-750 \\
750-1450 \\
1450 \\
1450-20\end{array}$ & $\begin{array}{c}2,0 \\
- \\
3,0 \\
5,0 \\
- \\
-5,0\end{array}$ & $\begin{array}{l}- \\
60 \\
- \\
- \\
60 \\
-\end{array}$ & $\begin{array}{l}\text { Отгонка пластификатора } \\
\text { Предварительное спекание } \\
\text { Окончательное спекание } \\
\text { Охлаждение }\end{array}$ \\
\hline 2 & $\begin{array}{c}\leq 350 \\
350 \\
350-750 \\
750-1450 \\
1450 \\
1450-1280 \\
1280 \\
1280-20\end{array}$ & $\begin{array}{c}2,0 \\
- \\
3,0 \\
5,0 \\
- \\
-3,2 \\
- \\
-5,0\end{array}$ & $\begin{array}{l}- \\
60 \\
- \\
- \\
60 \\
- \\
60 \\
-\end{array}$ & $\begin{array}{l}\text { Отгонка пластификатора } \\
\text { Предварительное спекание } \\
\text { Окончательное спекание } \\
\text { Охлаждение } \\
\text { Выдержка } \\
\text { Охлаждение }\end{array}$ \\
\hline 3 & $\begin{array}{c}\leq 350 \\
350 \\
350-750 \\
750-1450 \\
1450 \\
1450-900 \\
900 \\
900-20\end{array}$ & $\begin{array}{l}2,0 \\
- \\
3,0 \\
5,0 \\
- \\
-3,2 \\
- \\
-5,0\end{array}$ & $\begin{array}{l}- \\
60 \\
- \\
- \\
60 \\
- \\
60 \\
-\end{array}$ & $\begin{array}{l}\text { Отгонка пластификатора } \\
\text { Предварительное спекание } \\
\text { Окончательное спекание } \\
\text { Охлаждение } \\
\text { Выдержка } \\
\text { Охлаждение }\end{array}$ \\
\hline 4 & $\begin{array}{c}\leq 350 \\
350 \\
350-750 \\
750-1450 \\
1450 \\
1450-600 \\
600 \\
600-20\end{array}$ & $\begin{array}{c}2,0 \\
- \\
3 \\
5 \\
- \\
-3,2 \\
- \\
-5\end{array}$ & $\begin{array}{l}- \\
60 \\
- \\
- \\
60 \\
- \\
60 \\
-\end{array}$ & $\begin{array}{l}\text { Отгонка пластификатора } \\
\text { Предварительное спекание } \\
\text { Окончательное спекание } \\
\text { Охлаждение } \\
\text { Выдержка } \\
\text { Охлаждение }\end{array}$ \\
\hline
\end{tabular}

Графики описанных режимов представлены на рис.2. 
До $750{ }^{\circ} \mathrm{C}$ спекание проводят в протоке водорода, с 750 до $1450{ }^{\circ} \mathrm{C}$ - в вакууме для облегчения процесса уплотнения, удаления газов из пористых заготовок и обеспечения лучшей смачиваемости карбидов кобальтом. На максимальной температуре $1450{ }^{\circ} \mathrm{C}$ в течение 15 мин подается аргон под давлением 60 бар, затем для модернизированной технологии охлаждали до температуры $600,900,1280{ }^{\circ} \mathrm{C}$ соответственно для разных режимов. В конце режима проводили охлаждение садки с печью до температуры окружающей среды.

Обсуждение. На полученных экспериментальных образцах были проведены измерения ряда характерных свойств (табл.2).

Таблица 2

Результаты измерений физико-механических свойств

\begin{tabular}{c|c|c|c|c}
\hline Режим термообработки & Плотность, г/см & Твердость, HV 10 & Коэрцитивная сила, эрстед & Трещиностойкость, МПа·м ${ }^{1 / 2}$ \\
\hline 1 & 13,97 & 1033 & 78 & 10,59 \\
2 & 14,0 & 1088 & 98 & 10,79 \\
3 & 14,1 & 1222 & 116 & 11,70 \\
4 & 14,07 & 1153 & 107 & 11,05
\end{tabular}

Плотность определяли по ГОСТ 200818-74 на измерителе плотности VIBRA HT224RCE. Измерение твердости по методу Виккерса проводили на микротвердомере ПМТ-3 с максимальной нагрузкой 200 г, измерение коэрцитивной силы - на приборе «Кобальт-1» согласно ГОСТ 24916-81.

Анализ полученных данных подтверждает эффективность модернизированных технологий. Незначительное увеличение плотности тем не менее свидетельствует о том, что термообработка приводит к снижению дефектов типа остаточных пор. Повышение коэрцитивной силы и твердости позволяет судить об увеличении дисперсности зерен, так как известно, что это косвенные показатели измельчения структуры в твердых сплавах.

Наглядный сравнительный анализ данных свойств, полученных для трех экспериментальных режимов, представлен на рис.3.

Так как движению трещины препятствуют границы зерен и иные структурные несовершенства, наблюдаемое увеличение вязкости разрушения можно объяснить потребностью в до-
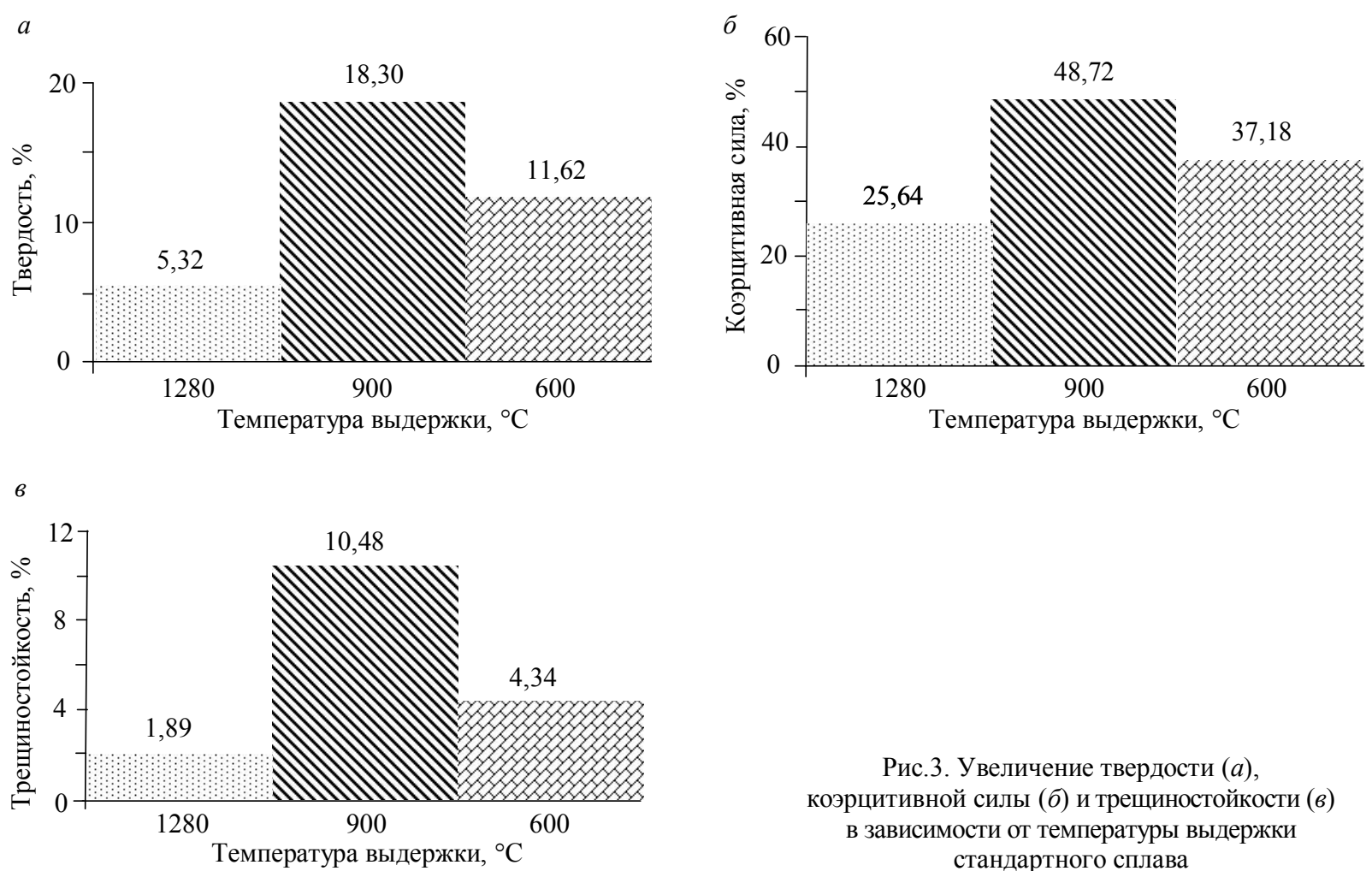

Рис.3. Увеличение твердости (a), коэрцитивной силы (б) и трещиностойкости (b) в зависимости от температуры выдержки стандартного сплава 
Результаты металлографического исследования и анализа распределения зерен

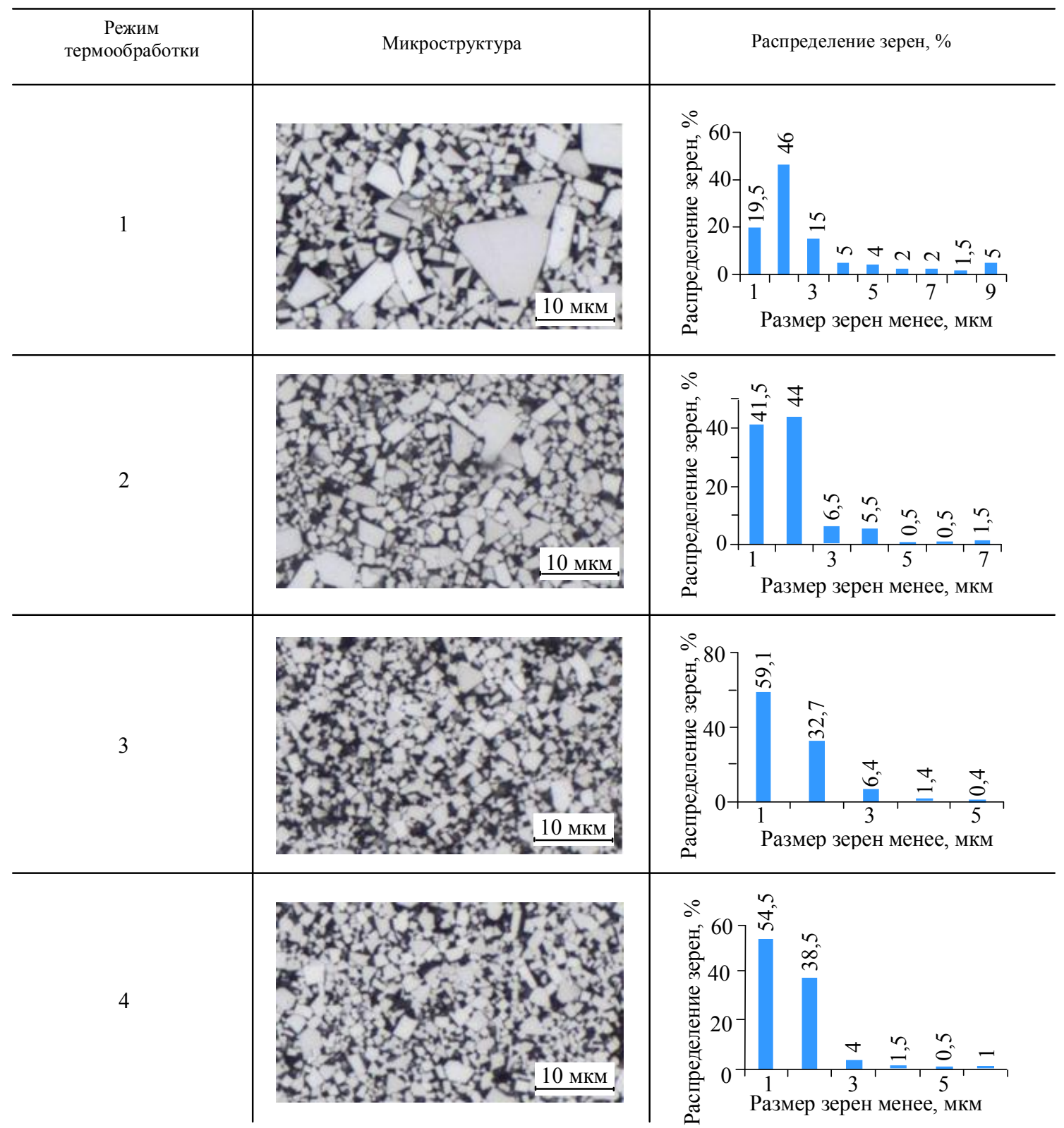

полнительной энергии на развитие трещины. Результаты металлографического исследования, осуществляемого на микроскопе «Carl Zeiss», и анализа распределения зерен карбида вольфрама в сплавах представлены в табл.3.

Анализ структуры демонстрирует видимое измельчение карбидной фазы после термообработки. Так, при традиционном спекании количество зерен карбида вольфрама средним размером менее 1мкм в диаметре от всего размерного диапазона достигает $19,5 \%$, в то время как после дополнительной обработки с выдержкой 1280; $900 ; 600{ }^{\circ} \mathrm{C}-41,5 ; 59,1 ; 54,5 \%$ соответственно.

В большей степени эффект измельчения, равнозначно как относительный прирост свойств, демонстрирует сплав после дополнительной выдержки при $900{ }^{\circ} \mathrm{C}$ (см. табл.2, режим 3).

При сопоставлении данных всего исследования установлено, что именно для этого режима наблюдается максимальное из исследуемых экспериментальных образцов увеличение твердости на $18 \%$, коэрцитивной силы - на $49 \%$, трещиностойкости - на $11 \%$ относительно характеристик материала заготовок, полученных по традиционной технологии. Выдвинута гипотеза о формировании дополнительных структурных элементов, не видимых при оптической металлографии. Увеличение твердости и вязкости приводит к увеличению эксплуатационной стойкости бурового инструмента и снижению затрат на бурение промышленных скважин. 


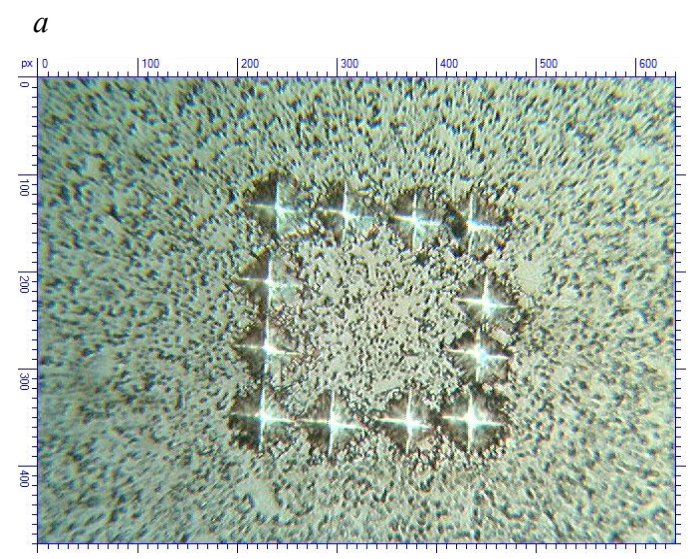

B

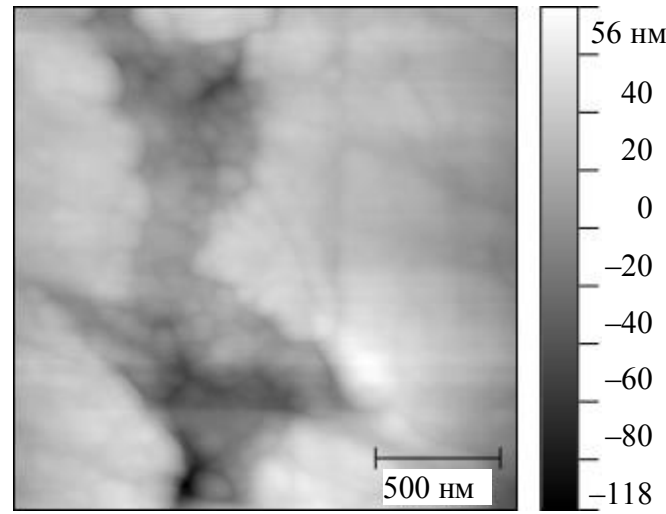

$\sigma$

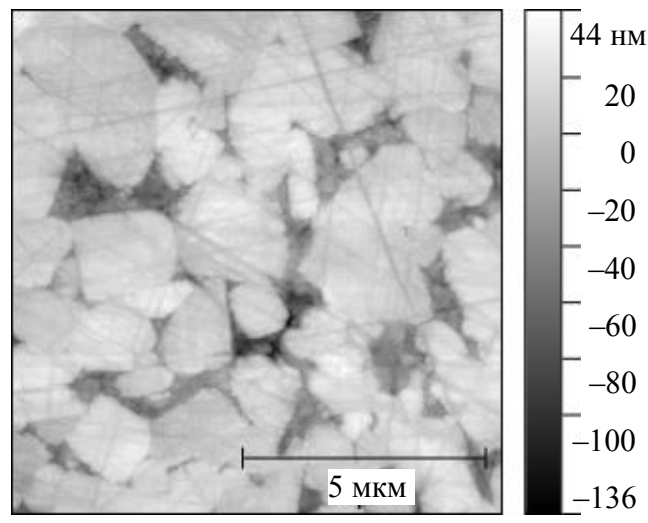

2

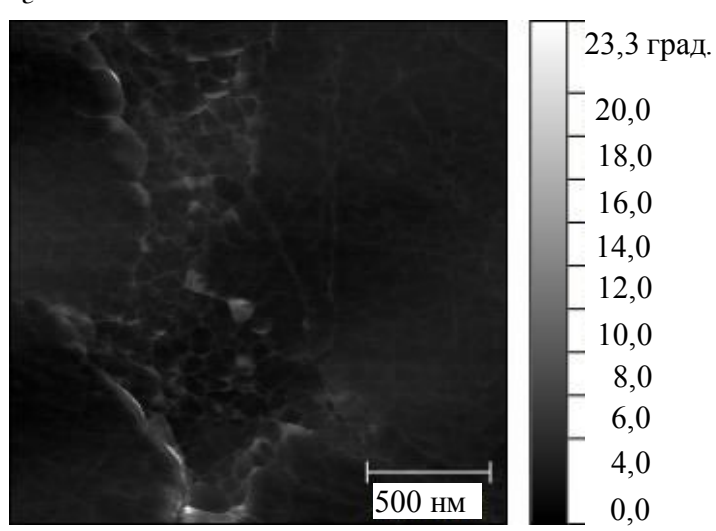

Рис.4. Результаты сканирования на атомно-силовом микроскопе: $a$ и $\sigma$ - область $40 \times 40$ мкм на образце; в и г - кадр АСМ-сканирования образца в области 3 на 3 мкм и при разности фаз соответственно

Для подтверждения предположения в центре коллективного пользования «Научнообразовательный центр «Функциональные микронаносистемы» проведено исследование неоднородности строения кобальтовой связки на образце, полученном по режиму 3 на атомносиловом микроскопе с использованием уникальных научных установок. Результаты исследований представлены на рис. 4.

Исследования топологии и структуры образцов подтвердили наличие наноразмерных включений, предположительно карбида вольфрама, в кобальтовой связке. Выявлен характерный размер включений от 20 до 40 нм.

Заключение. В ходе работы установлено, что условия спекания, а именно сочетание температуры и скорости нагрева и охлаждения, температуры и времени выдержки, температурного интервала дополнительной термообработки значимо влияют на структурные превращения, и, следовательно, могут являться механизмом управления свойствами твердого сплава. Так, для ВК15 сравнительные исследования свойств и анализ микроструктуры экспериментальных образцов, полученных по традиционному режиму спекания и по разработанной технологи спекания, показали, что режим спекания, дополненный выдержкой при $900{ }^{\circ} \mathrm{C}$, является приоритетным.

Таким образом, разработанная технология, включающая спекание порошков в протоке водорода до $750{ }^{\circ} \mathrm{C}$, с 750 до $1450{ }^{\circ} \mathrm{C}$ в вакууме, подачу на максимальной температуре $1450{ }^{\circ} \mathrm{C}$ в течение 15 мин аргона под давлением 60 бар, последующее охлаждение с печью до $900{ }^{\circ} \mathrm{C}$ и выдержку в течение часа, может быть рекомендована как наиболее рациональная для раскрытия потенциала материала и обеспечения повышенного уровня свойств бурового инструмента.

Благодарность: Работа выполнена при финансовой поддержке прикладных научных исследований Министерством образования и науки Российской Федерации. Соглашение о предоставлении субсидии №14.579.21.093. Уникальный идентификатор RFMEFI57915Х0093. 


\section{ЛИТЕРАТУРА}

1. Влияние добавок керамических наночастиц на структурные параметры и свойства твердых сплавов / Ю.И.Гордеев, А.К.Абкарян, Г.М.Зеер, А.А.Лепешев // Вестник СибГАУ. 2013. № 3. С. 49-54.

2. Захаров Д.А. Совершенствование состава, структуры, технологии и применения твердых сплавов в производстве буровых шарошечных долот: Автореф. дис... канд. техн. наук / Самарский государственный технический университет. Самара, 2014. 22 с.

3. Новый твердый сплав с наноупрочненной связкой / И.Ю.Коняшин, Б.Рис, Ф.Лахманн, А.А.Мазилкин, Б.Б.Страумал // Материаловедение. 2010. № 3. С.38-40.

4. Особенности уплотнения при спекании сплава ВН8М с добавками наноразмерного карбида вольфрама / Д.В.Федоров, О.В.Семенов, В.И.Румянцев, С.С.Орданьян // Порошковая металлургия и функциональные покрытия. 2014. № 3. C. 26-30. DOI: 10.17073/1997-308X-2014-3-26-30

5. Панов В.С. Технология и свойства спеченных твердых сплавов / В.С.Панов, В.Н.Шуменко. М.: Изд-во МИСиС, 2013. $144 \mathrm{c}$.

6. Панина К.С. Разработка технологии получения твердых сплавов с повышенными механическими свойствами на основе сплава ВК15 // Всероссийская научно-техническая конференция «Студенческая научная весна. Машиностроительные технологии»: Материалы конференции, 4-7 апреля, 2017 / МГТУ им. Н.Э.Баумана. M. URL: studvesna.ru?go=articles\&id=1984 (дата обращения: 27.09.2017).

7. Патент 2548846 РФ. Способ получения спеченных твердых сплавов / Ю.И.Гордеев. Опубл. 27.12.2011. Бюл. № 11.

8. Патент 2534670 РФ. Способ упрочнения твердых сплавов / С.И.Богодухов. Опубл.10.12.2014. Бюл. № 34.

9. Патент 2631548 РФ. Способ получения изделий из твердого сплава на основе карбида вольфрама / П.С.Бешенков, Р.Ю.Куфтырев. Опубл.27.09.2017 Бюл. № 27.

10. Borovskii G.V. Nanostructured hard metals WC-Co produced from plasma chemical powders / G.V.Borovskii, Y.V.Blagoveshchenskii, A.V.Abramov // RWF Werbegesellschaft. Austria. 2009. Iss. 2. P. 224- 229. P.23-26.

11. Bartha L. Investigation of hip-sintering of nanocrystalline WC/Co powder/ L.Bartha, P.Atato, A.L.Toth // Materials. 2000. Iss. 32.

12. Jia K. Microstructure, hardness, and toughness of nanostructured and conventional WC-Co composites / K.Jia, T.E.Fischer, B.Gallois // Nanostructural materials. 1998. Iss. 10. P. 875-891.

13. Patent 20080179104 USA. Nano-reinforced WC-Co for improved properties / Y.Zhang. Opubl. 31.07.2008.

14. Patent 20140023546 USA. Cemented carbide material / I.Yu.Konyashin, B.H.Ries, F.F.Lachmann. Opubl. 23.01.2014.

15. Patent 6524366 USA. Method of Forming Nanograin Tungsten Carbide and Recycling Tungsten Carbide / P.Seegopaul, L.Gao. Opubl.25.02.2003.

16. Tan G.L. Preparation and mechanical properties of nanostructured tungsten carbide alloys strengthened by carbon nanotubes / G.L.Tan, X.J.Wu, Z.Q.Li // MRS Proceedings. 2003. Iss. 788. P. 449.

17. Z.Fang. Synthesis, sintering and mechanical properties of nanocrystallaine cemented tungsten carbide / Z.Fang, X.Wang, T.Ryu // Metals Hard Mater. 2009. Iss. 27. P. 288-299.

Aвторы: Ю.А.Курганова, д-р техн. наук, профессор, kurganova_ya@таil.ru (Московский государственный технический университет им. Н.Э.Баумана, Москва, Россия), К.С.Панина, сотрудник лаборатории, kirapaпinaтgtи@таil.ru (Московский государственный технический университет им. Н.Э.Баумана, Москва, Россия), П.С.Бешенков, инженер-технолог, pbeshenkov@gmail.com (ООО «Завод технической керамики», г. Апрелевка, Московская обл., Россия).

Статья поступила в редакиию 20.12.2017.

Статья принята к публикащии 08.05.2018. 